\title{
Integrity of the Halal Supply Chain Conceptual Framework
}

\author{
Ahmad Hidayat Sutawijaya ${ }^{1^{*}}$, Lenny C NAwangsari ${ }^{2}$ \\ ${ }^{I}$ Doctoral Program, Faculty of Pascasarjana, University Mercu Buana, Indonesia \\ ${ }^{2}$ Magister Management, Faculty of Pascasarjana, University Mercu Buana, Indonesia
}

*Corresponding Author: Ahmad Hidayat Sutawijaya, Doctoral Program, Faculty of Pascasarjana, University Mercu Buana, Indonesia

\begin{abstract}
Purpose: The development of halal has become life style for the majority of muslims. Consumers of muslims in the whole world must ensure that the food that they eat in accordance with requirements Islamic law. This is also strategy for the adoption of catering to the supply chain. This study attempts to create designs over supply chain in catering company in Jakarta. The purpose of this research is to produce new paradigm in halal supply chain catering industry.
\end{abstract}

Design/Methodology: This study presents the results of discussions about the halal supply chain framework at catering companies in Jakarta through a triangulation approach and supported by literature.

Research Limitations/Implications: This research only focuses on Diamond catering companies in Jakarta. Loyal consumers provide an evaluation of the services provided by the company.

Keywords: Halal Supply Chain, Supply ChainManagement, Catering

\section{INTRODUCTION}

The pew research center study of religion on public life projecting \& population of the muslim world is expected to rise about 35 percent in 20 years ahead, up from 1,6 billion in 2010 and 2,2 billion in to 2030. (https://databoks.katadata.co.id, 2017).Indonesian Muslim population in Indonesia is estimated to reach 238.8 million. Based on the 2010 Population census population percentage Muslim Indonesia reached 87.18 percent (CBS, 2018). Food, drugs, cosmetics and personal care each day is very important and daily human needs required by modern society (Mursyidi, 2013). However, the Moslem population has strict regulations to consume and use. Islam has standardized that food, drugs, cosmetics and personal care must meet kosher standards.

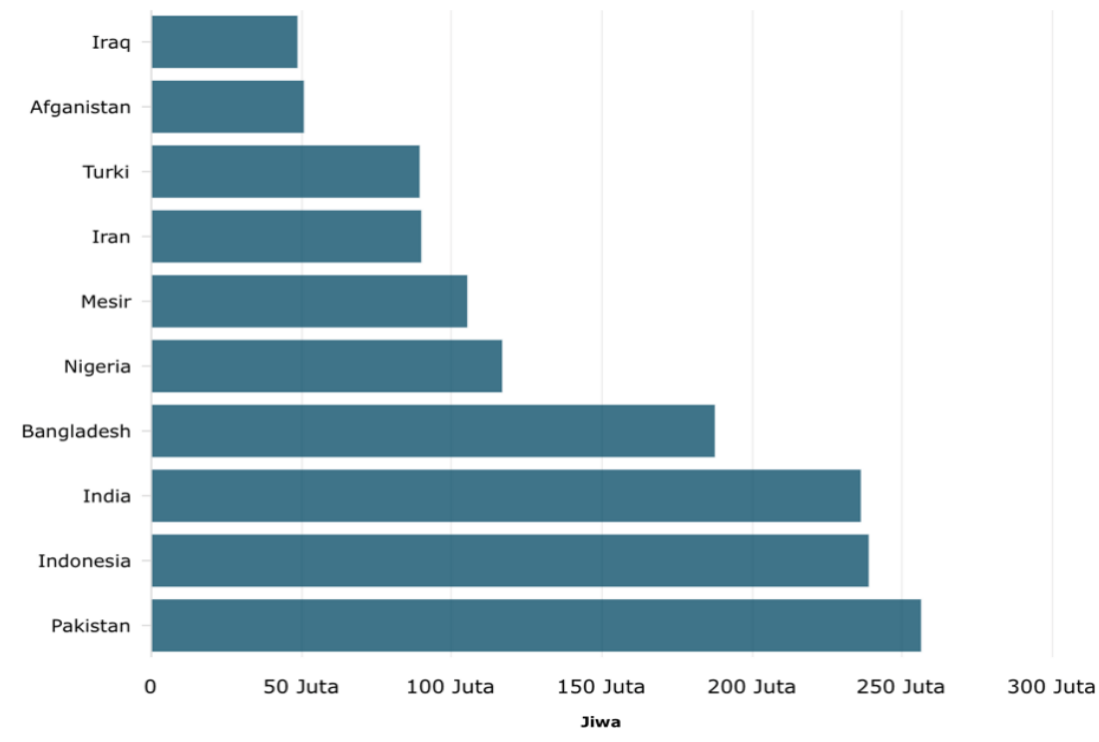

Figure1: Ten World's Biggest Islamic Population in 2030 
Source: https://databoks.katadata.co.id/datapublish/2017

\section{STUDY OF LiTERATURE}

\subsection{Supply Chain}

Supply Chain Management (SCM) is a physical network consisting of a series of company companies involved in providing raw materials, producing goods, or sending them to customers or end users. By managing information flow, product flow, and material flow between suppliers and distributors using Supply Chain Management (Ahmad H Sutawidjaya, Lenny Nawangsari, 2018). According to Pujawan (2005), the definition of a supply chain is a network of companies that work to create and deliver a product to the end user together. According to Heizer and Render (2005), the definition of supply chain management (SCM) is the integration of material procurement and service activities, conversion into semi-finished goods, and final products, as well as shipping to customers.

\subsection{Halal Supply Chain}

Halal supply chain management is an activity to use resources effectively in the entire supply chain starting from the raw material to the final product in the hands of consumers to ensure food security in the supply chain, especially for halal. The legal code for living Islam that has been declared and ordered by Allah is known as Shariah which means "Islamic law". According to Syaria, the consumption of halal food (halal) and toyyib (healthy) and abstaining from haram (breaking the law) are very important to protect faith, life, dignity / lineage, intelligence and Islamic property.

\subsection{Catering Wedding Organizer}

Catering begins with the term to cater which means for preparation and serving food and drinks to the public. Someone who prepares and serves food is called a caterer. The food or catering service industry includes restaurants, offices, hospitals, cafeterias and other places (https://gocatering.id).

Catering is a business providing food services in the necessary places such as hotels, homes, councils or other areas. Catering has changed to become an important business. The catering has now developed business by giving more experience than just food (https://ms.wikipedia. org/wiki).

\section{RESEARCH METHODOLOGY}

The type of research design used in this study is descriptive qualitative which is describing, describing, and describing the object under study (Arikunto, 2006: 11). According to Lexy J. Moleong (2005: 6), qualitative research methods are research that intends to understand the phenomena experienced by the subject of research.

Meanwhile Sugiyono (2009: 15) says, the notion of qualitative research is research that is based on post positivism philosophy, used to examine the condition of natural objects, (as opposed to experiments) where the researcher is a key instrument, purposive sampling of data sources and snowball, a tri-grafting (combined) collection technique, data analysis is inductive or qualitative, and the results of qualitative research emphasize the meaning rather than generalization.

This research was designed as an exploration study with the general objective of evaluating supply chain activities in terms of the process of interfacing between companies and suppliers in production.

\section{RESULTS AND DISCUSSION}

From the picture above it can be concluded that for the successful implementation of the halal supply chain in the company of course it must follow the steps as follows:

\subsection{Business Strategic}

The Global Supply Chain Forum has identified eight main supply chain business strategies (Lambert et al., 1998): customer relationship management, customer service management, demand management, order fulfillment, manufacturing management flow, procurement, product development and commercialization, and returns. For halal food supply chains, the supply chain business processes customer fulfillment orders, management of production and procurement flows is of particular importance. The process of fulfilling customer orders brings separation requirements from customers (market objectives) throughout the supply chain. Manufacturing flow management is the physical handling of halal products throughout the supply chain, where halal control activities and guarantee 
activities need to be formulated to extend halal integrity from the source to the point of consumer purchase. This process also includes logistics. Finally procurement is very important in the halal food supply chain, for that role in defining and managing the structure of upstream supply chain networks through commodity strategies (purchasing strategies); determine specifications, supplier selection and integration (tactical purchases); and ordering, accelerating and evaluating suppliers (order functions) (van Weele, 2002; Kraljic, 1983; Wagner and Johnson, 2004). As stated by Cousins et al. (2008) the role of socialization mechanisms, a means by which the involvement of suppliers value halal values, is very important because it fully mediates the effect of supplier performance measures on supply chain performance.

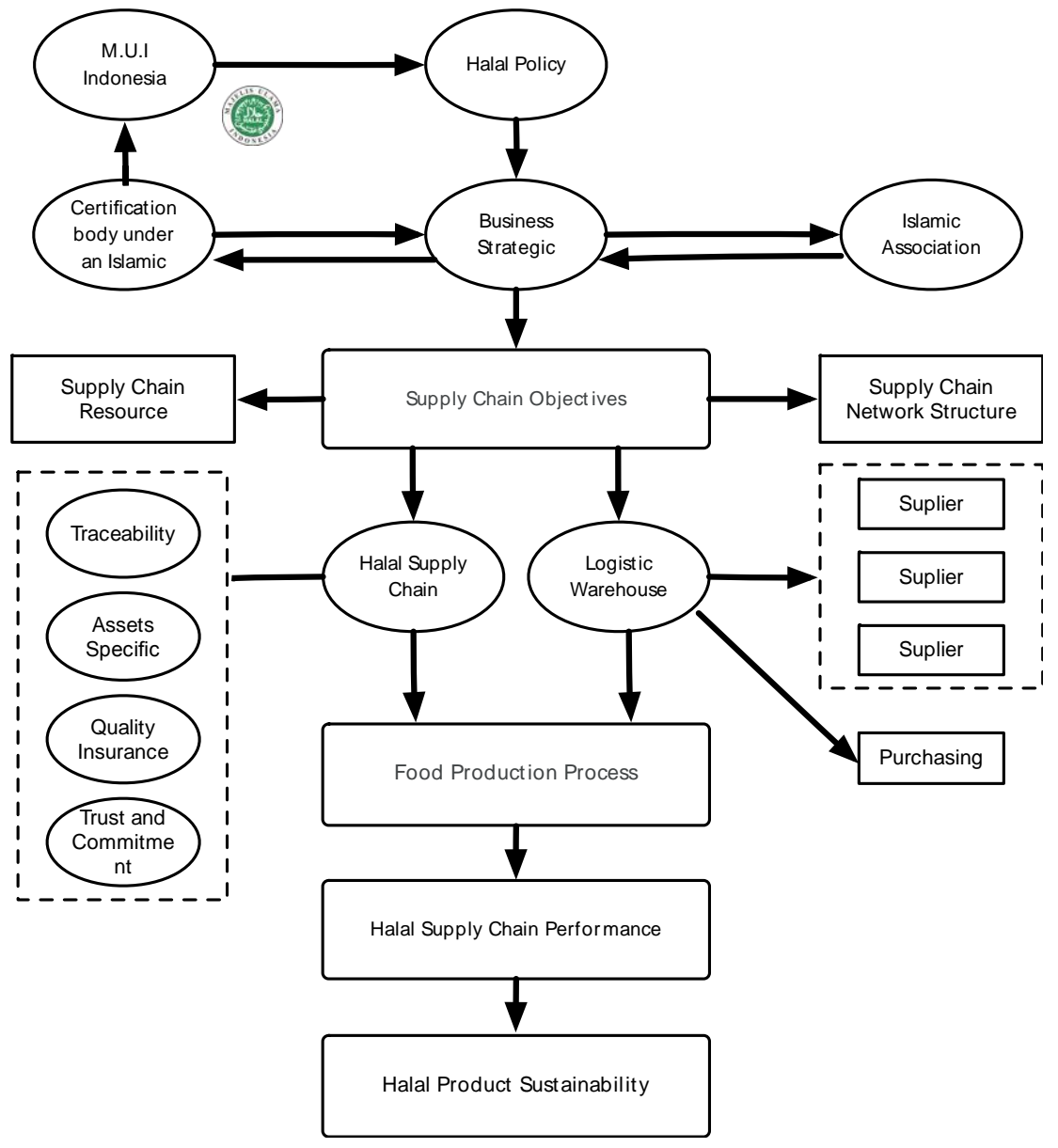

Figure2: Concepts Integration Halal Supply Chain

\subsection{Halal Policy\& Supply Chain Objectives}

The first step in developing the concept of halal supply chain integration is to ensure the right intention (Alserhan, 2010). Therefore, halal requires commitment from the top management level through halal policy (Indonesian Ulama Council, 2010), which acts as the basis for supply chain organizations. Among other things, halal policy: the responsibility of the organization in protecting halal integrity with the supply chain; scope of halal certification of the organization; guarantee for consumers or customers (promises); and guarantee method (control mechanism; covering aspects such as halal committee, halal compliance officer and inspection). In line with an inseparable demand and supply chain model (van Amstel and van Goor, 2001) and a framework for chain / network development for the food supply chain (van der Vorst and Beulens, 2002), supply chain objectives (logistics and customer service ) objectives) are being formulated that direct the design parameters (Schnetzler et al., 2007) of the halal food supply chain.

\subsection{Supply Chain Network Structure}

The structure of a supply chain network is a network of connected and interdependent organizations working together and cooperatively to manage, control and increase the flow of material and information (Aitken, 1998). Halal food supply chains (Bonne and Verbeke, 2008; Zailani et al., 2010) and configuration supply chains are vulnerable to being a source of risk (Olson and $\mathrm{Wu}, 2010)$ : 
partner-related risks as well as internal organizational processes in risk assessment and response. For the integrity of the halal supply chain, it is very important for parties in halal-certified halal supply (preferred) or understanding and complying with halal supply chain requirements. Because the integrity of the supply chain is a function of the integrity of supply chain partners, the choice of supply chain partners must receive the highest priority in the design of the supply chain network structure. Similar to organic supply chains (Claro and de Oliveira Claro, 2004), there is a preference for simple supply chain structures and the need for coordination in halal supply chains.

\subsection{Logistic Warehouse}

Warehouse Halal logistics is the heartbeat of the halal supply chain model, which provides the foundation for effective decision making and supply chain management (van Damme, 2000). van Amstel (2002) defines logistical control as an organization, planning and controlling the flow of goods, from development, purchasing, through manufacturing and distribution to end consumers with the aim of meeting customer needs at low costs and with controlled capital use. Among other things, an important element in logistical control is (van der Vorst, 2000): hierarchy at the level of decisions (Hofmann, 2010), types of decision making (Manuj and Sahin, 2011), customer order point positions (CODP) (Olhager, 2010; Sun et al., 2008) and the level of coordination (Naspetti et al., 2011). According to Seuring (2009) and Peterson (2002) integrated supply chains can only be optimized when chain components function together to improve the supply chain as a whole. This requires coordination. Aken (1994) distinguishes four forms of coordination, based on leverage (power, influence) and impact (direct indirect). Produces four quadrants:

- Regulate coordination (indirect impact and power);

- Conditional coordination (indirect impact and influence);

- Coordinate (direct impact and power); and

- Encourage coordination (direct impact and influence).

Coordination according to Aken (1994) classification of the best halal supply chain can be classified as "regulatory coordination" (indirect impact and power) because halal and halal logistics are equipped with standards. However, with cross-border supply chains, there are various halal standards involved. This power is indirect through standardization of tasks and procedures to ensure coordination and standardization of output (van Amstel, 2002). For halal supply chains, it is important that the supply chain is in line with the requirements of the destination market. These minimum requirements, as logistical design parameters, must be shared throughout the supply chain.

Regarding the management of supply chain partners, Kraljic's (1983) approach to supplying management provides useful insights (Gelderman and van Weele, 2003). In his book the approach to changing supplier and base purchases is analyzed based on two variables (van Weele, 2002): supplier impact on financial results (measured in the cost of purchasing certain product categories or impacting product quality) and inventory risk (measured based on criteria such as the number of potential suppliers, supply availability, competitive structure in the supply market). The halal implications for purchasing portfolio matrices and inventory management strategies have two possible effects. First, halal has an impact on financial results for producers of halal sensitive products, namely: "Do animal products have standards?" [Yes No]. Examples of animal products are raw meat, processed meat and animal additives (such as gelatin). Second, halal impacts on supply risk: "Are those supply chain partners based in non-Muslim countries?" [Yes / no] Partners in non-Muslim countries that offer halal-compatible products and services have invested in halal certification / compliance, specialized and often not well controlled and supported by the government in terms of halal compliance.This requires a more intensive relationship with supply chain partners, which drives the traditional routine supply of chain partners to the leveraged bottleneck or supply chain partners for countries nonMuslim.

\subsection{Supply Chain Resources}

Supply chain resources describe organization and information management. For a halal-certified organization halal committees (Department of Standards Malaysia, 2005, 2010a, b, c; Port of Rotterdam, 2007) are needed. The halal committee is responsible for complying with management and practices in accordance with halal standards. The halal committee prepares halal policies, which 
are supported by the managing director / CEO of the company. This halal committee is better if it has halal compliance officers who act as internal auditors, but can also be left to independent parties (not halal certification companies).

\subsection{Halal Supply Chain}

\subsubsection{Traceability}

Traceability is defined as the ability to track history, the location of what is being considered in accordance with the International Organization for Standardization (ISO) and traceability is a series of identifications recorded. Some define traceability as the ability to follow and document the origin and history of a food product; from core genetics to dinner plates, tracing involves identifying all the procedures and practices that are owned that have an impact on the life of a product, and are documented and available to buyers or other supply chain participants to see. Traceability is a method of providing safer food supplies and connecting producers and consumers (Regattieri, Gamberi et al. 2007). To achieve the concept of traceability, search technology must include and imply in the supply chain. Radio Frequency Identification (RFID) is a suitable technology that can track and track, forward, and reverse a history of data.

\subsubsection{Assets Specific}

A phrase used in buyer and seller relationships to understand the relative balance of power between the parties when one or both parties invest in assets that may be uniquely applied only to the other party. The concept is especially relevant in cooperative relationships, where parties may invest in customer specific assets based on longer term commitments. See also Supplier Relationship Management.

\subsubsection{Quality Insurance}

Resources: quality, as an objective dimension as considered a critical factor. Grunert (2005) distinguishes two dimensions of food quality, namely objective and subjective. A holistic view of food quality is detected when the concept of halal is combined with the concept of thoyyiban, both of which are related to the safety, nutritional content and aesthetic appeal of halal products.

In addition, the quality of resources is distinguished from the purity of resources because quality usually involves food technologies such as shelf life, freshness, size and taste. Sources of purity can only be achieved by following certain halal processing requirements. Although there is a very thin line that distinguishes the quality of purity in the halal context, there are circumstances where halal food products do not meet the quality criteria requested and vice versa. For example, meat from cows that experience a halal slaughter process is considered pure and satisfying beef but the fat content in meat may not meet the quality requirements. Moreover, the quality of halal food depends not only on the quality of the company's own products but also on the quality of suppliers (Tse and Tan, 2011). Therefore, unobservable quality of resources can endanger the integrity of halal food.

\subsubsection{Trusted Commitment}

\subsubsection{Food Production Process}

The food production process focuses on ensuring processes, management systems and facilities. Focus on efforts to maintain integrity such as internal systems and production strategies. Globally, being certified as a halal producer is now seen as bringing profit competitiveness by utilizing the Muslim market (Zakaria, 2008). However, halal food producers in Indonesia no longer view certification as a competitive weapon but as a basic need, because the majority of the population are Muslims and consider certification to have a major influence on purchasing decisions (Alam and Sayuti, 2011; Suddin et al., 2009). Therefore, manufacturers are highly oriented towards certification, even though halal certification is voluntary.

A number of studies have revealed that compliance with standards and regulations can benefit companies in various economies of scale. Therefore, stakeholders from the food supply chain will try to develop, determine, and improve new norms and certification schemes (Savov and Kouzmanov, 2009; Trienekens and Zuurbier, 2008). MS1500: 2009 standard is one of the leading halal standards in the world (Lever and Miele, 2012). Especially, MS1500: 2009 is considered a new concept in marketing but this is also a benchmark for halal food producers (Daud et al., 2011). However, the 
application of MS1500: 2009 is treated as stand-alone and not implemented together with other types of standards available, in part because this is not regulated in MS1500: 2009. MS1500: 2009 can be seen as a general consolidation of production guidelines for the halal food industry. It is estimated that there are 122 halal certification institutions that are active throughout the world with different halal standards (Halim and Salleh, 2012). Thus, the nature of standards is very common and applies to many types of halal food producers. There are studies that claim that food quality has specific halal standards such as placing higher requirements that can improve food quality (Trienekens and Zuurbier, 2008). However, Magkos et al. (2006) claim that implementing one standard is not enough and will only focus on one aspect of food quality.

\subsection{Halal Supply Chain Performance}

Current supply chain performance measurement systems are mainly related to costs and are not inclusive (Estampe et al., 2010; Aramyan et al., 2007, Bhagwat and Sharma, 2007; Chia et al., 2009). However, there are several examples of frameworks that more balanced, such as the conceptual framework of performance indicators of the agriculture-food supply chain (Aramyan et al., 2006) and various balanced scorecard perspectives. But even this balanced metric does not have a measurement of aspects of halal product trust, Islamic value factors are also a resilience requirement. Therefore, this metric will not be effective in optimizing the halal supply chain. For the halal food industry to optimize their supply chains, it must include new indicators in their performance measurement systems to ensure that their supply chains are not only efficient, but also effective in protecting halal integrity and strong in the implementation of its supply chain.

To measure the performance of the halal supply chain, the most important thing is to measure the perspective of supply chain effectiveness. This will discuss two key aspects, namely the quality of the process (Andersen, 1994; Bonne and Verbeke, 2008) and waste (Abdul-Matin, 2010). Process quality shows the strength / trust of a brand credibility of halal certificates and consumer complaints received regarding the halal status of a product. Garbage addresses physical waste in the supply chain, carbon footprint and resources used. Waste occurs in the supply chain and also by end consumers. Waste in the supply chain can be avoided or minimized by using the right (reusable) packaging for transportation and environmental control (temperature and humidity level). Waste by end consumers is more difficult to manage from the supply chain, but it can overcome, for example, consumer packaging that does not burden the environment or buy products that have lower food mileage (Lammers et al., 2010). Although miles of food are easily calculated and are relevant indicators for sustainability, due to their limitations with the high impact of transportation modes, efficiency and differences in transportation in food production systems on the sustainability of food supply chains (Smith et al., 2005; Weber and Matthews, 2008 ; Coley et al., 2011). At present, the carbon footprint has become a key measurement of environmental impacts in SCM (Lee and Cheong, 2011; Wiedmann and Minx, 2008; Svensson and Wagner, 2011). As current energy consumption is mainly based on non-renewable energy, energy consumption is an important indicator of measuring waste in the halal supply chain (Abdul-Matin, 2010).

Second, the halal supply chain must also be efficient to avoid escalating the price of halal food. This will affect especially Muslim consumers living in non-Muslim countries, which will create difficulties (Laldin, 2006) for them. Efficiency can first be measured by SCM costs. Furthermore, halal will require special logistics infrastructure, suitable indicators can become halal utilization of storage and transportation facilities / halal containers.

Third, the halal supply chain must be strong in design to better protect halal products along the supply chain under different circumstances (Tieman, 2011). An important strategy is the development of a strong alliance network, reduction lead-time and efficient coordination (Lammers et al., 2009; Tang, 2006). Its strength from the halal supply chain must first produce a slight halal rejection. Second, halal supply chains must have adequate access to halal and halal warehouses specifically for transportation / containers when needed.

\section{CONCLUSION}

Halal products and services are an important requirement for Muslim communities. The more competition in the product, the company is required to improve the quality of goods and halal guarantees. Halal products are goods or services produced through a process based on Islamic law. 
The halal implementation of supply chain in the company will be implemented if the halal supply chain framework is clear.

The concept of halal supply chain begins with the clarity of the company's business strategy supported by the Indonesian Ulema Council (MUI) and Muslim unions accredited by the religious department. Next is the clear goal of the concept of Supply Chain in the company. At this stage we divide the two, there is the concept of halal supply chain and wharehouse logistical concept. Halal supply chain concept implementation consists of 4 indicators of success, namely Traceability, Specific Assets, Quality Insurance, Trusted Commitment. Meanwhile wharehouse logistics consists of several successful inductors such as purchasing and suppliers. So that if the two supply chain concept targets are well implemented, they will enter the food production process stage and be followed up with supply chain halal measurements. The output is supply chain sustainability.

According to Talib, Hamid, and Zulfakar (2015) research, the key to success for implementing halal supply chain management is government support, the existence of special assets in the form of special armadars, information technology support, adequate human resources; vertical and horizontal collaborative relationships, in the form of trust, transparency, information disclosure; and finally halal certification.

\section{ACKNOWLEDGEMENTS}

The author would like to thank all the staff, managers and leaders of Diamond Organizer for their important contributions to service, attention and helpful comments.

\section{REFERENCES}

[1] Ahmad Hidayat Sutawidjaya, Lenny C Nawangsari. (2017). A Framework Model on Supply Chain Event Organization (Cases in Event Organizer, Jakarta), Review of Integrative Business and Economics Research 6, 277

[2] AlessandroAgnetis (2006), Supply chain scheduling: Sequence coordination, elsevier 2006

[3] Alexander E. Ellinger (2011), Supply Chain Management Competency and Firm Financial Success, Journal of Business Logistics, 2011, 32(3): 214-226

[4] Alexander Ellinge (2012), The influence of supply chain management competency on customer satisfaction and shareholder value, Supply Chain Management: An International Journal 17/3 (2012) 249-262

[5] Bukhori et al (2015), Evaluation of Poultry Supply Chain Performance in XYZ Slaughtering House Yogyakarta using SCOR and AHP Method.

[6] Christopher Roethlein and Sara Ackerson (2004), Quality communication within a connected manufacturing supply chain. emerald

[7] Matthew H. Sauber (2008), Developing supply chain management program: a competency model,

[8] Muhammad dan Yuslidar (2012), Evaluasi Penegelolaan Kinerja Rantai pasok dengan Pendekatan SCOR Model pada Swalayan Asiamart Lhokseumawe

[9] Mursyidi. 2013. Akuntansi Pemerintahan di Indonesia, Cetakan Kedua. Bandung:Refika Aditama

[10] Palma-Mendoza, J.A (2014), Analytical Hierarchy Process and SCOR Model to Support Supply Chain Re-Design.

[11] Perdana dan Ambarwati (2012), Penentuan Prioritas Perbaikan Kinerja Supply Chain Menggunakan Metode Analytical Network Process.

[12] Pujawan, I.Y, (2005). Supply Chain Management. Surabaya: Guna Widya Quality Assurance in Education Vol. 16 No. 4, 2008 pp. 375-391

[13] Reza Babazadeh (2013), Facility location in responsive and flexible supply chain network design (SCND) considering outsourcing, Int. J. Operational Research, Vol. 17, No. 3, 2013

[14] Robert E Spekman (2002), Supply chain competency: Learning as a key component',Supply chain management: An International Jurnal vol 7 number 1

[15] Regattieri, Gamberi et al. (2007), Traceability of Food Products: General Framework and Experimental Evidence, Journal of Food Engineering 81(2):347-356

[16] Setiadi et al (2018), Analisis Kinerja Rantai Pasok Ikan Nila pada Bandar Sriandoyo di Kecamatan Tugumulyo Kabupaten Musi Rawas.

[17] Sunhee Youn (2012), Integrative leadership for effective supply chain implementation: An empirical study of Korean firms, Int.J.Production Economic 139 (2012) 237-246

[18] Sutawijaya dan Marlapa (2016), Supply Chain Management: Analisi dan Penerapan Menggunakan Reference (SCOR) di PT Indoturbine 
[19] Tieman (2012), Principles in halal supply chain management, Faculty of Business Management, Universiti Tecknology MARA, Shah Alam, Malaysia.

[20] Talib, Hamid, dan Zulfakar (2015), Journal of Islamic Marketing, emerald, ISSN: 1759-0833.

[21] Vinhv Thai (2012), Competency requirements for professionals in logistics and supply chain management, International Journal of Logistics: Research and Applications Vol. 15, No. 2,April 2012, 109-126

[22] Xiaolong Xue (2005), An agent-based framework for supply chain coordination in construction, Automation in Construction 14 pg 413-430

[23] https://databoks.katadata.co.id, 2017.

[24] https://databoks.katadata.co.id/datapublish/2017

\section{AUTHOR BIOGRAPHY}

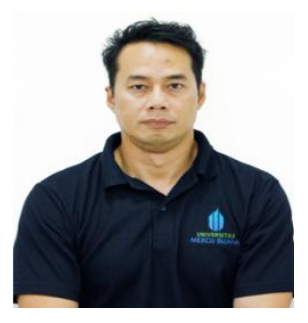

Achmad H Sutawidjaya obtained his Doctor of Business Administration (DBA) degree from San Beda College, Business School, Manila, Philippines in 2008. The Master of Commerce (M.Com) degree was obtained at the University of Wollongong, Australia in 1997. 2013, Suta join Mercu Buana University. Various researches and scientific journals have been published, both within Mercu Buana University or in several universities in Indonesia and Abroad, especially those related to operations management.

Citation: Ahmad Hidayat Sutawijaya, Lenny C NAwangsari. "Integrity of the Halal Supply Chain Conceptual Framework" International Journal of Managerial Studies and Research (IJMSR), vol 7, no. 10, 2019, pp. 18-25. doi: http://dx. doi.org/10.20431/2349-0349.0710003.

Copyright: (C) 2019 Authors. This is an open-access article distributed under the terms of the Creative Commons Attribution License, which permits unrestricted use, distribution, and reproduction in any medium, provided the original author and source are credited. 